\title{
On Time and Discipline in Islam (Analysis towards Purpose of Islamic Education)
}

\author{
Dinasril Amir \\ Department of Islamic Education, Faculty of Education and Teacher Training \\ IAIN IB Padang, Indonesia \\ E-mail: dinasrilamir@yahoo.com \\ DOI: http://dx.doi.org/10.15548/jt.v21i3.107
}

\begin{abstract}
This article contains elucidation about punctuality issues and discipline in educational perspective. From the discussion that has been done it can be said that punctuality problems and discipline are very important and vital in building good and advanced of human life, because it is related to the basic, function and purpose of education as well as the teachings of Islam. Punctuality and discipline are a fundamental goal of the educational efforts and Islamic Shari'ah. In Islam, there are many concepts related to punctuality and discipline. They are obedience, self-control and behavior, submission and obedience, as well as support for the values and rules of the understanding, comprehension, awareness and responsibility. Being punctuality and discipline have to be owned and improved in education and life, and in turn, the family, society and the environment should support it in order to achieve the progress.
\end{abstract}

Keywords: On time, discipline, education, religion, obedience and progress.

\section{INTRODUCTION}

On time problem and discipline concerns loyalty, obedience, obedience, fidelity, surveillance, habit formation, mental and moral training with system security maintenance and order in human life (Komarudin, 1994). On time issue and discipline are principles and important aspect of human life that their teachings contained in the culture, customs, religion and spiritual life of the people and Indonesia nation. Therefore on time and discipline problems are summarized in the discipline closely connected with the national education system wanted to be established by the state and the people of Indonesia, especially education in the meaning of moral and ethics. The success of Indonesia's development in the education field for the intellectual life of the nation and developing human fully are determined by the discipline factors of society and the nation itself. Whether the discipline in personal life, family, communities, countries, or in religion life (Government Regulation Number 20 Tahun 2003. Thus it can be said that discipline is a society life principle and the fundamental of the development success or progress of a nation. In general, the developed nations in the world are caused by having the discipline and high work ethic, such as Japan and Korea are two nations that have high discipline in their life, beside motivation and work ethic (Efendi, 2005).

The discipline that is a principle and an important part of national life as well as society and religion today is felt to experience meaning shallowness and weak of soul and spirit, so that they cause insecurity and disorder which in turn can disrupt aptness of national life and the development of human beings. For example, among the public and the younger generation there are an unbelief attitude and disobedience. Though in Islam there is only prohibition to not comply creatures (humans), when he or she was in error and disobedience to God. "There is not devotion to the creature in disobedience to Khaliq (Bukhari, 1967).

Discipline crisis in Indonesia today cannot be denied. According to Fuad Hasan (Former Minister): "The Indonesian nation 
today is experiencing a discipline crisis. On the highway, for example, the street vendors (PKL) take the shoulder of the road to sell, defectors who do not heed the presence of the bridge crossing, and so on. He said, such behavior is not dealt well (Hasan, 2005).

As a result of the lack of discipline, a lot of people and the younger generation forget their duties and responsibilities as well as rights and obligations, they could be more reluctant to participate and give a sincere devotion to the development in the reform era. If the discipline problem is not owned by the people and the nation of Indonesia, the ideals and goals of national development to create a state apparatuses that are clean as well as respectable and safe and orderly society will not be realized.

In undergoing the reform era and facing the 21 st century facing towards civil society, it needs to be fostered and developed discipline in personal life, family, community, nation and religion because the discipline is goal of national development. Discipline as a national development objectives is defined in the Guidelines of State Policy (GBHN) in the field of socio-cultural development among other things say that social responsibility and national discipline are nurtured and developed more tangiblely in an effort to strengthen national solidarity, embed more tolerant stance, frugal and simple, hard-working, meticulous, orderly, full of devotion, honest and knights. In the Guidelines year 1999-2004 discipline problems include in Indonesian vision. Indonesian vision in the future according to the Guidelines of Indonesian society is the realization of a peaceful, democratic, equitable, data competitiveness, advance and prosper within the Republic of Indonesia, supported by the Indonesian human self, faith, piety, morality, patriotism, law awareness and environment, mastering science and technology, having a high work ethic, and discipline (Pabelan, 2002).

Efforts to build a nation that is based on Pancasila and the 1945 Constitution, embody civil society, strengthen national identity, reinforce self-esteem and national pride, and strengthen the national unity spirit to realize at the will of the guidelines, except after citizenries have responsibility and high national discipline. So discipline is the mandate of the Guidelines discipline in development effort, especially in education sector.

Discipline problems are still interesting to be studied, because the discipline as one of the goals of education naturally has not been reached. Time management and discipline level of Indonesian society in everyday life are still in low level, the problems this phenomenon, for example, it is real in the traffic discipline, meetings, keeping promises and appreciating the time. So far, the problem has been the characteristic of Indonesian society that is Muslim majority, whereas that the characteristic neither come from Islam nor the purpose of education. This paper wants to explain how the discipline become important goal of Islamic education.

\section{EDUCATION REALATIONSHIP WITH DISCIPLINE}

Education can be interpreted simply as a effort (processes) in changing attitudes and behavior of a person or group of people in exertion maturing human through the efforts of teaching and training, maintenance and care, as well as the love and affection or attempt teach, love and care. In terms education is an effort to educate through teaching, loving and caring in Islam contain in Tarbiyah definition are as teaching, taklim as loving, and ta'dib as caring. In this sense education is an effort to educate through caring, loving and caring in order not to wrong in facing students' life. In Law No. 2 about National Education System formulate that education is a conscious effort to prepare students through counseling, teaching, and / or training for their role in the future Terayon (1990). While in Law R.I. No. 20 year 2003 on National Education System formulated that education is a conscious and deliberate effort to create an learning atmosphere and the learning process so that learners actively developing their potential to him to have the spiritual religious, self-control, personality, intelligence, noble character, and skills needed by 
themselves, society, nation and state (SISDIKNAS, 2002).

In two definitions or formulations are confirmed that the effort to educate through the attempt to teach, love and care should be done with full awareness planning as well as projected for the students preparedness to face the future or era. In Islam people are awakened and commanded to educate their children based on the role and the era in the future. This is consistent with what said by the Prophet Muhammad in the following hadith which means:

"Teach your children! They are created to face era with the times (the future) which is not equal to your era", (Bukhari, 1996).

From what has been said can be affirmed that education as a process or action is a noble effort, because an attempt to glorify the human kamanusiaan. By education people can come to their glory as creatures of God, the Almighty. Man as God's most precious creatures (good) shape of events is confirmed by the Qur'an in the following verse, which means:

"We have created made man in the form of events as honor as form (ahsantaqwin) "(Surah al-Tin verse 4)

Besides education has a noble definition, it also has high purpose to human life for its role in the future. Indonesia in National Education System formulates educational purposes as an effort to educate the nation and develop human whole (Terayon, 1990). While in the National Education System year 2003 is enhanced and developed further, that national education has function to develop skills, form the character and prestigious civilization in educating the nation, aimed to develop the students' potential to become a man that have faith and fear to God Almighty, noble, healthy, knowledgeable, skilled, creative, independent, and become democratic and responsible citizen. Intelligence and human wholeness is defined in broad definition includes intellectual, emotional, social, creativity, moral character and religion intelligence (faith and devotion) as required and want to develop nowadays and future. Humans fully are humans that have faithful and devotion to God Almighty, noble character, knowledge and skills, spiritual and physical healthy, steady and independent personality, and have social and national responsibility. So the formation of man who wants to be addressed by the education is a smart man and intact (noble) in humanity.

One characteristic of an intelligent man and intact is discipline. Discipline human is one of the human characters to be formed by the goal of education, both general and religious education, because discipline people are obedience, submissive, and stand firm on the values of truth and rules so that their life are orderly and organized. Aptness and wholeness will lose its height and perfection that if there is no discipline in life. While the discipline itself can only be obtained through teaching training and education, it relates to educational objectives that have been proposed, such as faith and devotion, self-control and responsibility. Thus education is closely related to the effort in forming discipline of human life as learners.

\section{DISCIPLINE AS ONE OF THE GOALS OF ISLAMIC EDUCATION.}

In Indonesian Great Dictionary (KBBI) religious education is activities in education and teaching field with the main target to give conviction and religious knowledge as well as the establishment of religious attitudes and behavior so that learners obey in religious to Allah SWT. In this definition religious education is narrower than education in general. The main task of religious education is only to guide and develop potential of learners. While education generally have task to build and develop human potential in all aspects of human life activity that includes physical, spiritual, moral, social, art, intellectual and diversity of learners (Jaya, 1999). The essence of religious education is an attempt to glorify the learners' potential diversity in order to become discipline human (obedient and submissive) to Allah. The definition of Islamic religious education is religious education that 
has meaning and values of Islam. In this definition it is broader than Islamic education, such as the extent of general education than religious education.

Since the extent of Islamic education definition, it also differs in the two purposes. The difference in the meaning of Islamic education goal is broader than Islamic educational purposes. The aim of Islamic education is limited to create the intellectual in religious field. In short educational goal is the intelligence establishment and human submissive in religion. According to Rahman (2003), the purpose of religious education is the formation of man (the students) that have faith and fear of Allah, like sacrifice, resignation, discipline and patient (Rahman, 2003). In this definition religious education is directed to the purpose of religious learning (learning how to believe in God), not the destination that is now applied in schools that just memorize it. Religious education in learning / teaching that emphasizes religious memory that will not be able to form learners that faith and fear of Allah, like sacrifice, resignation, discipline and patience. The purpose of religious education can only be realized in self-learners by developing understanding on the study of religion or religious counseling.

From the description mentioned above can be affirmed that discipline is one of Islamic education goal that is very important and the concept is found in faith and piety. Said to be very important, because disciplinary problems are as one of the goals of religious education is closely related to other religious educational purposes. It means faith and piety, like sacrifice, resignation and patient will not be realized without high discipline. Discipline can be regarded as a decisive factor for the attainment of other educational goals, because discipline concerns obedience as the primary goal of Islamic education. Discipline became religious purposes because discipline is safety and success key of human life. Triumph of man in a effort done is very dependent on skill, dedication, discipline. In short people have to discipline themselves in order not to waste time and success in life. You must discipline yourself so that you do not waste time, says the Arab proverb that says time is like a sword. If a person cannot use it, it will cut off his neck. Another Proverb also said that at that time is money. All expressions of proverbs in line with Allah utterance in Surah al-Ashr emphasizes how important and vital discipline in order people do not lose money and superfluous in life. Clearly Allah in Surah al-Ashr says, which means:

$$
\begin{aligned}
& \text { "By the time, men are really in loss, } \\
& \text { except those who believe and do pious } \\
& \text { deed and advise to obey truth and } \\
& \text { advised to keep patient." }
\end{aligned}
$$

\section{DEFINITION OF DISCIPLINE IN THE ISLAMIC EDUCATIONAL PURPOSES.}

The word discipline comes from the English, the dicipline which means discipline or order. In Indonesian Great Dictionary (1989) defined discipline with 1). The rules (schools, military,), 2) Adherence (compliance) to the disciplinary rules, and 3). A field of study that has an object, system and certain method. Definition for number 1 and 2 relate to the purpose of religious education. In Malay Dictionary (Bilingual) discipline is defined 1). Training, especially of thought and behavior, to guard self. 2). Good behavior (behavior obey the rules), students are educated (educated) perfectly, show good behavior in front of guests. 3) Regulations are applied by good behavior. In this definition discipline is emphasized its meaning to people who know themselves and have a good thought and behavior. Psychology emphasizes discipline meaning to self control by purpose to resist impulses that are not unwanted habits or check habit. Psychology emphasizes the discipline meaning to self control. Self control is the ability to guide own behavior to prevent behavior that is not suitable with conscience. Control behavior in psychology is pursued through reward and punishment (Warren, 1993).

In management, a discipline is defined a circumstances that create an orderly atmosphere 
that is produced by people under the auspices of an organization where the regulations are respected and followed. Thus definition is emphasized in management. Dead discipline in management science is a discipline without initiative, whereas life discipline gives the freedom to take initiatives along the strategy lines that has been determined. In the education field (schooling), discipline is defined as a certain degree of orderly to achieve good conditions to fulfill the functions of education. Discipline in education can also be interpreted as training, teaching or education that is meant to instill a obedience, certain social norms. Education emphasizes discipline definition toward orderly, good and instill dutiful based on human behavior (the learners). In the military sector discipline is understood as obedience to superiors, carrying out all orders, and (of course also) leave any restrictions. Besides, there are many religions talk about discipline. Discipline is essentially a religious term, because the meaning originally is the follower or adherent. In this definition Muslims are followers of Muhammad Prophet and the religion he brought (Islam). They obey Muhammad Prophet and obey the teachings of Islam. In terms of religious discipline can be defined as a mental, orderly, tawadu', submissive, obedient and happy to follow the leadership of the Muhammad Prophet and the religion he brought, namely Islam. So discipline is a religious concept that is initially cored on obedience in, faith and fear. While the other disciplines in life follow thereafter. Thus among the sense of discipline that can be raised from a variety of disciplines that can be tracked.

Various definitions of disciplines above are stated clearly that have broad definition and meaning. The definition of discipline is not only limited to the followers or adherents, but it includes in order meaning, obedience and compliance, attitudes, thinking and good behavior, self-control, orderly atmosphere as well as dynamic and full of initiative, compliance and obedience, high loyalty to the leadership, and obedience soul, happy (sami'na wa atha'na). In short discipline is a exquisite behavior, noble nature, main characteristics, positive psychology, and good conditions that must be possessed by every human being in every aspect of life and activity. Therefore, discipline should be the goal of education and the life of every human being in every shape, type, and level. Discipline people know themselves, their God and their environment.

Discipline definition in religious education in principle is not much different from what has been stated above, because a review of discipline in terms of education and religion has already been discussed. However, to explanation and assertion further it's good also formulated in religious education can be interpreted as the training, learning, or education aimed at developing the competence and attitude of obedience without disobedience and denying in doing orders or norms or teachings, and so on which may be legal, command, or the system relate to time and space with all dimensions of the learners. Growing definition of sami'na wa atha'na as intended by the Qur'an surah Al Baqarah verse 285 in diversity spirit among students is the sense of discipline in the Islamic educational purposes. Exalted moral formation, noble, good attitude, good psychological and mental, self-control and ability to implement rules / regulations by full adherence to the students are also among the intended definition of discipline by Islamic education. Discipline in the opposite definition to the nature of Islamic education can be defined as the proud, lawless, bad morals, disrespectful and uncivilized, to misbehave and reckless, inhumane and so on. Therefore, high discipline in life is coveted by education. Discipline people in the view of Islamic education people know God, fellows, the environment and themselves (Jaya, 1999). Life dimension is not only horizontal or the individual, but also vertical and ecological. Thus discipline ideally as one of the Islamic education goal both outward and inward.

\section{CONCLUSION}

From the descriptions that have been said can be concluded that the discipline is the main attitude in human life. It becomes the purpose of education and human life, it becomes the safety and success principal. Because the 
discipline is important for human life then education should try as optimum as possible to realize goal of discipline in educational activities. Islamic education generally or particularly is very concerned with the achievement of the discipline goals of learners. All educational activities are required to achieve the goals of the discipline of the learners. Therefore, the discipline has a broad definition and in the Islamic education system, at least, the discipline as one of the education goals can be interpreted as training, learning or education to develop the competence and attitude of obedience without disobedience, denying toward in doing an order, norms, teachings so that may be legal, orders, appointments, or mandate that all systems related to space and time with all dimensions and potential. Attitude sami'na wa motto atha'na is a disciplined life in Islamic education system.

Based on the conclusions of discipline definition above, then it is recommended to any Islamic educators to enhance their efforts in developing the discipline mission of their learners through the development of the vision, mission, action, and technique in instilling discipline in education field. On families, communities and the environment in order to show the behavior - the disciplines behavior, so that students in the school are motivated by habituation, learning and deepening a given discipline, so with that came a sense of fairness and do not blame the schools alone. Discipline crisis outside of school usually have significant impact on education in the schools, because the crisis of discipline mentality can agglomerate into undiscipline, even it can worsen (Hasan, 1990).

\section{REFERENCES}

\section{Bukhari, U. (2010). Ilmu Pendidikan Islam, Jakartas.}

Caplin, C.P, Kamus Psikologi. (Terjemahan). Jakarta: Rajawali.
Dewan Bahasa \& Pustaka, Kamus Dwi Bahasa. (1990). Kuala Lumpur: Kementrian Pendidikan Malaysia.

Darwis, D. (2010) .Dinamika Pendidikan Islam, Sejarah Ragam dan Kelembagaan. Semarang: Rasail.

Echols, J.M. \& Shadily, H. (1981) Kamus Inggris Indonesia: Jakarta: Gramedia.

Howard C.Warren, Dictionary of Psychology, Cambridge, The Ribersibe Press, 1934.

Imam Bukhri, Shahih al-Bukhri, Kitab "Akhbar al-Ahad" (Beirut,Al-Maktabah 1967)

Jaya, Y. (1993). Spiritualisasi Islam Dalam Menumbuhkembangkan Kepribadi-an dan Kesehatan Mental. Jakarta: Ruhama Press.

Jaya, Y. (1999). Psikoterapi Agama Islam. Padang: IAIN Press.

Jaya, Y. (2000). Bimbingan Konseling Agama Islam. Padang: Angkasa Press.

Langgulung, H. (1990). Manusia dan Pendidikan. Jakarta: Alhusna Zikra Press.

Komaruddin. (1994). Ensiklopedi Manajemen. Jakarta ; Bumi Aksara.

Lembaran Negara; Undang-Undang Republik Indonesia, nomor 20 tahun 2003 tentang Sistim Pendidikan Nasional, tahun 2003.

Muhaimin, H. (2001)Pemikiran dan Aktualisasi Pengembangan Pendidikan Islam, Jakarta, Rajawali Press.

Pabelan. (1998). GBHN 1998 beserta Susunan Kabinet Pembangunan VII: Surakarta: Pabelan Press.

Pusat Pembinaan dan Pengembangan Bahasa Depdikbud. (1994). Kamus Besar Bahasa Indonesia. Jakarta: Balai Pustaka. 
Pustaka Setia. (2002). Undang-Undang Dasar 1945 Sesudah Amandemen ke Empat, Tahun 2002. Bandung: Pustaka Setia Press.

Poerbakawaca, S \& Harahap, A.A. (1982) Ensiklopedi Pendidikan. Jakarta: Gunung Agung Press.

Ramayulis. (2008). Ilmu Pendidikan Islam. Jakarta: Kalam Mulia Press.

Terayon, G. 1990. Sistem Pendidikan Nasional. Jakarta:Golden Terayon Press.

Tim ENI, Ensiklopedi Nasional Indonesia 4, (Jakarta ; Cipta Adi Pustaka, 1989).

Unicef. (1996). Metode Islami dalam Perawatan Anak. Jakarta: Unicef.

Westra, R. (1977). (Ed), Ensiklopedi Administrasi. Jakarta: Gunung Agung Press.

Yafie, A. (1997). Teologi Sosial. Jakarta: LKPSM. 